\title{
Ecophysiological Responses to Environmental Pollution of Selected Plant Species in an Industrial Urban Area
}

\author{
Iryna Skrynetska ${ }^{1}$ (1) $\cdot$ Ryszard Ciepał $^{1} \cdot$ Marta Kandziora-Ciupa $^{1} \cdot$ Gabriela Barczyk $^{1} \cdot$ Aleksandra Nadgórska-Socha $^{1}$
}

Received: 12 November 2017/Revised: 26 March 2018 / Accepted: 2 April 2018 / Published online: 9 April 2018

(C) The Author(s) 2018

\begin{abstract}
The aim of the study was to determine the state of the environment in Sosnowiec (southern Poland) based on the ratio of air pollution tolerance index (APTI) and the determination of concentrations of selected metals in soil and plant material. The study was conducted in ten stands: five of them were identified as 'polluted' and five as 'clean' stands. The metal content was evaluated by the atomic absorption method. For APTI calculation, analysis of total chlorophyll concentration and relative water content, the $\mathrm{pH}$ of the extract from the leaves was used. Analysis of the bioaccumulation of metals in the leaves revealed excessive concentrations of $\mathrm{Pb}\left(32.4 \mathrm{mg} \mathrm{kg}^{-1}\right)$ and $\mathrm{Zn}\left(129.78 \mathrm{mg} \mathrm{kg}^{-1}\right)$ at the KWK (coal mine) and Las (forest) stands. Higher capacity accumulation of $\mathrm{Pb}$ and $\mathrm{Fe}$ was characteristic for Plantago lanceolata. The permitted content of $\mathrm{Pb}\left(762.6 \mathrm{mg} \mathrm{kg}^{-1}\right)$ in the soil samples collected at the Cedler stand was exceeded. Elevated levels, higher than the permissible concentration of $\mathrm{Cd}$, were documented in soil samples from most stands within the city. In soil samples collected at the Cedler stand, Cd concentration was almost 15 times higher than acceptable for soil $\left(4 \mathrm{mg} \mathrm{kg}^{-1}\right)$. Based on the scope of the APTI 4.4-9.42 index obtained for the studied species, they should be considered sensitive plants. All selected species can be used as bioindicators for environmental pollution.
\end{abstract}

Keywords Air pollution tolerance index $\cdot$ Heavy metals $\cdot$ Soil pollution $\cdot$ Plants $\cdot$ Silesia

\section{Introduction}

Air pollution is one of the most complex problems in the contemporary world. As a side effect of urbanisation and industrialisation, it is a factor responsible for many negative impacts affecting the well-being of fauna and flora, as well as the environment as a whole. Air pollution can affect plants directly through the leaves, as well as indirectly by the acidification of the soil environment (Kumar and Nandini 2013). The effects of atmospheric pollution are generally observed on leaves because they are the first receptors (Randhi and Reddy 2012). Many studies have also showed that the majority of plants exposed to polluted atmosphere first have physiological changes before visible damage to the leaves (Abida and Harikrishna 2010).

Iryna Skrynetska

i.skrynetska@gmail.com

1 Department of Ecology, Faculty of Biology and Environmental Protection, University of Silesia, Bankowa 9, 40-007 Katowice, Poland
Although a review on the use of plant species in controlling air pollution has already been carried out, there has been no extensive review on the use of anatomical, morphological, physiological and biochemical parameters of plants of urban biotopes as biomarkers of environmental pollution (Uka et al. 2017).

Sosnowiec is one of the main cities in the Silesian conurbation (in the southern part of Poland, Fig. 1), whose history is closely associated with heavy industry, including mining, metallurgy and chemical plants. It is a typical example of a city that has been affected by intense anthropogenic transformation. The plant species growing here are exposed to high concentrations of heavy metals in the environment, both for economic reasons (mainly the still active mines) and also from sources related to transport, which is associated with the existence of a number of roads with heavy traffic, as Sosnowiec is one of the most important transport hubs in the Silesian province. The city is located at the intersection of highways connecting the northern parts of Europe with the south, and western parts with the east, making up the majority of the domestic and 


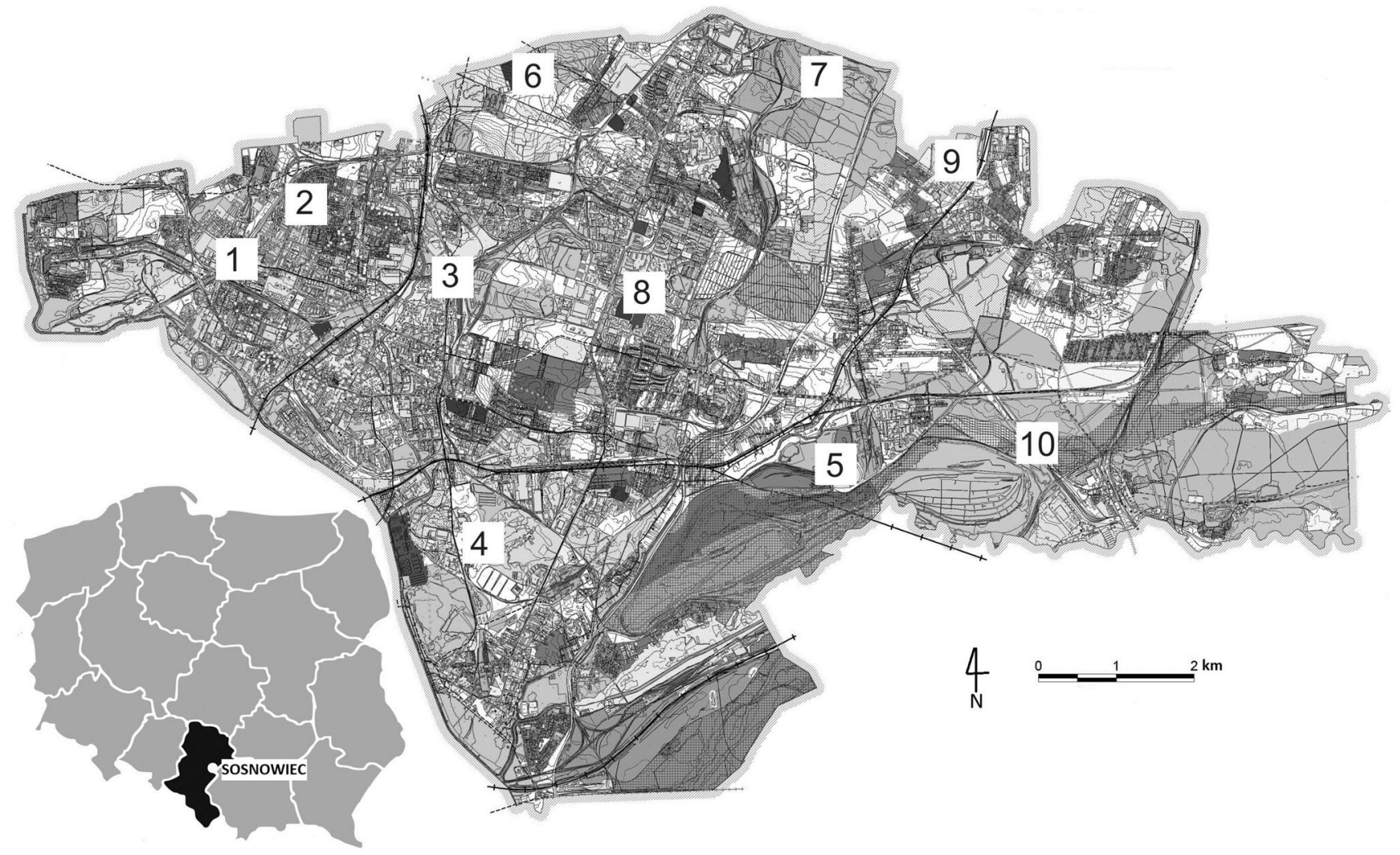

Fig. 1 Map of localisation of study stands in Sosnowiec: 1—expressway S86; 2—Buczek; 3-KWK; 4—Cedler; 5—Juliusz; 6—Sokolska; 7— Zagórze; 8-Kukułki; 9—Las; 10-Klimontów

international transits. Nevertheless, even with such heavy loads of pollutants, Sosnowiec is still a city with numerous green areas. In recent years, works related to the rehabilitation of mining areas have been undertaken and actions aimed at identifying sources of pollution, to bring the environment to a proper state ('Update Environment Program for the city of Sosnowiec for 2013-2016 with a perspective for the period 2017-2020'). Due to economic transformation in Poland in the 1990s, most metallurgical plants and mines in Silesia have been closed and, in consequence, metalliferous dust emission has significantly decreased. Nevertheless, the soil in the region is going to stay contaminated for many years to come (Dziubanek et al. 2015).

As demonstrated by numerous studies, some plant species have the ability to tolerate or accumulate pollutants, which is manifested in them to varying degrees. The taxa of plants that colonise a soil, which is full of heavy metals, are mandatory or optional metallophytes, with developed mechanisms of tolerance for high concentrations of some metals (Nadgórska-Socha et al. 2013a, b). Although the plants have metal-tolerant or bioaccumulation properties, heavy metals do interfere with their metabolism and consequently induce morphological and ecophysiological changes (Maleci et al. 2014).
The investigated areas represented various habitats (green belts, squares, fields, brownfields, lawns and forest) with ruderal and invasive species as Solidago canadensis and Reynoutria japonica. These two different species might be also good study material in future research according to their high tolerant properties to environmental pollution (Vanderhoeven et al. 2005, Dassonville et al. 2008; Mincheva et al. 2014).

Previous studies have indicated that the Plantago major and Plantago lanceolata species contain significant levels of trace elements, and the possibility of heavy metal accumulation from polluted environments has been noted (Tinkov et al. 2016). Robinia pseudoacacia has also been investigated as an indicator of soil pollution from $\mathrm{Zn}$ and $\mathrm{Cd}$, and determined as a sensitive biomarker species for contaminated areas (Nadgórska-Socha et al. 2016). In Denmark, scientists concluded that Achillea millefolium can be used to monitor $\mathrm{Cu}$ and $\mathrm{Pb}$ accumulation (Pilegaard and Johnsen 1984). Due to the wide geographic range of the selected species, they may also be widely used for research in environmental monitoring in Sosnowiec. In our research, we selected species due to their presence at the majority of the studied sites.

It is also well known that epidermis is the first target of atmospheric pollution, as the pollutant first passes through 
the stomata of the epidermal tissue. There are many biochemical mechanisms that help to adapt plants to atmospheric pollutants. This feedback can be assessed by a number of parameters, such as $\mathrm{pH}$, total chlorophyll, ascorbic acid and relative water content; all of these indexes make up the air pollution tolerance index. The value of air pollution tolerance index defines the plants' tolerance to pollution, because these parameters determine the plants' adaptation to the environment, and thus predetermine the species' sensitivity or resistance (Lakshmi et al. 2009).

The main advantage of bioindicative research is the use of plant material, which is a chance for long-term research without using expensive equipment (Nadgórska-Socha et al. 2013a, b). The goal of the study is to analyse the polluted areas; the results may be useful in assessing the plants' adaptive properties to harsh environmental conditions (Przedpełska and Wierzbicka 2007; Slomka et al. 2008). For this bioindicative research, ruderal plants were used (Kovacs 1992; Massa et al. 2010).

The objective of this study was to perform a comparative analysis of selected ecophysiological parameters and to determine the metal concentration in plants and soil from potentially clean stands concerning samples collected from potentially contaminated areas. The data obtained allowed us to analyse the air pollution tolerance index and assess the potential use of the tested species as bioindicators. The tolerance of plants to heavy metal toxicity has to be established to consider their possible application in soil phytostabilisation and revegetation in mining areas contaminated with heavy metals (Nadgórska-Socha et al. 2013a, b).

The following hypothesis was evaluated: heavy metal contamination contributes to changes in the ecophysiological responses in selected species within polluted sites and in comparison to plants from a non-contaminated area.

\section{Materials and Methods}

\section{Study Area}

The samples were collected in the city of Sosnowiec (Silesia), which is the main centre of the Upper Silesian Industrial District. Ten locations were selected: the first five areas were adjacent to the industrial plants, and the remaining five were chosen as non-industrial locations (Fig. 1). The plant's material and soil samples were harvested during the vegetation season of plants in late June and early July 2014.

The area near expressway S86, the former KWK Sosnowiec coal mine, the Buczek and Cedler metallurgy plants and the former Juliusz coal mine were selected as polluted study points. To represent non-industrial locations, the Sokolska, Kukulki, Zagórze, Klimontów and Las stands were selected as territories with residential and recreation zones (Fig. 1).

\section{The Soil and Plant Material}

For the study, plant materials derived from perennial herbaceous perennials were selected: greater plantain $(P$. major) and English plantain ( $P$. lanceolata) are species of Plantago, family Plantaginaceae; common yarrow (A. millefolium) is a flowering plant of the family Asteraceae; black locust ( $R$. pseudoacacia) is a tree in the family Fabaceae.

However, P. major was not found in the Zagórze and Kukułki stands. The same difficulties were noticed with $R$. pseudoacacia in the Las stand and with A. millefolium in the Zagórze stand.

The soil samples were taken from the top layer of the soil at $0-10 \mathrm{~cm}$. In the collection of the research material, attention was paid to the cleanliness and homogeneity of the samples. Topsoil samples were taken within the root zone at a depth of $0-10 \mathrm{~cm}$ and widely used in different environmental studies, for example Dao et al. (2014), Polechońska et al. (2013), Elnazer et al. (2015) and Kandziora-Ciupa et al. (2017). To reduce the heterogeneity, topsoil was sampled from five locations at each site (taken from $10 \mathrm{~m} \times 10 \mathrm{~m}$ plots at the central and four corner locations). The samples were sieved through a $2 \mathrm{~mm}$ mesh to remove stones and plant debris and mixed together to get a representative sample. The soil samples were transported in fabric bags to facilitate airflow and drying. Each sample's date and place of harvest were described. From each stand tested, the samples of soil and plant material were collected in five replicates.

\section{The pH Measurement, CNS Analysis and Metal Extraction}

The $\mathrm{pH}$ was examined by a standard method (Ostrowska et al. 1991). The CNS analyser (Variomax CNS) was used to measure the contents of $\mathrm{C}, \mathrm{N}$ and $\mathrm{S}$ in soil samples. The heavy metal content in the soil was determined in the samples collected in the city of Sosnowiec by using the atomic absorption spectrometry method. Soil samples were air-dried, sieved through a $2 \mathrm{~mm}$ mesh and stored at room temperature until analysis. The metal content of the soil was estimated according to the method by Ostrowska et al. (1991), described in detail by Nadgórska-Socha et al. (2013a, b). Metals were extracted from air-dried soil samples using $10 \% \mathrm{HNO}_{3}$. The $\mathrm{HNO}_{3}$-extractable fraction was obtained by shaking a sample $(10 \mathrm{~g})$ with $100 \mathrm{ml}$ of $10 \% \mathrm{HNO}_{3}$ for $1 \mathrm{~h}$. Finally, the content of metals was 
measured in the filtered extracts using atomic absorption spectroscopy.

The metal content in the plants was also measured by atomic absorption spectrometry. Plant samples were taken to the laboratory, thoroughly washed with tap water to remove any dust deposits and then rinsed twice with distilled water. Plant samples were dried at $105{ }^{\circ} \mathrm{C}$, and then plant tissues were ground in a stainless steel mill. Dry weight subsamples $(0.25 \mathrm{~g})$ were wet digested in concentrated $\mathrm{HNO}_{3}$ at the maximum of $120{ }^{\circ} \mathrm{C}$ and then diluted to $25 \mathrm{ml}$ with deionised water (Lin et al. 2008). Trace element contents $(\mathrm{Cd}, \mathrm{Pb}, \mathrm{Zn}, \mathrm{Fe}, \mathrm{Mn})$ were measured by atomic absorption spectrometer (Thermo Scientific ICE 3500 apparatus).

\section{Analysis of the Biochemical Parameters of the Plants}

The relative leaf water contents (RWC) for plant samples were determined by the methodology of Pathak et al. (2011) and calculated according to the following formula:

$\mathrm{RWC}=[(\mathrm{FW}-\mathrm{DW} / \mathrm{TW}-\mathrm{DW})] \times 100(\%)$,

where FW is the dry weight $(\mathrm{g})$, TW the turgid weight (g) and DW the dry weight $(\mathrm{g})$.

The contents of total chlorophyll and ascorbic acid in plant material were quantitatively determined (Prajapati and Tripathi 2008).

Quantitative determination of total chlorophyll. The method was used in accordance with the determinants of Arnon (1949). $0.5 \mathrm{~g}$ of leaves was homogenised in $80 \%$ acetone solution, then decanted and filtered through a filter paper. The extraction was repeated and washed with acetone until discolouration of the solution. After that, the sample was supplemented with acetone to $50 \mathrm{ml}$ and the absorbance measured at wavelengths of 645, 663 and $652 \mathrm{~nm}$.

Quantitative determination of ascorbic acid. The method according to the recommendations of Keller and Schwanger (1977) and previously described in detail in Nadgórska-Socha et al. (2016) was used. The ascorbic acid contents were calculated with the following formula:

Ascorbic acid $=\frac{(C-A-B) \times V}{W \times 100} \times 100\left(\mathrm{mg} \mathrm{g}^{-1}\right.$ f.w. $)$,

where $V$ is the volume of the extract $(\mathrm{ml}), W$ is the weight of the leaf sample $(\mathrm{g})$, and $A, B, C$ are the optical densities of the blank sample, plant sample and sample with ascorbic acid.

Calculation of the APTI (air pollution tolerance index). The air pollution tolerance index value allows us to define the degree of a plant's tolerance to environmental pollution. The most popular method is division into three classes/groups according to the level of sensitivity (Singh and Rao 1983):

APTI $<10=$ sensitive

$10<$ APTI $<16=$ medium sensitive

APTI $>17=$ resistant.

For calculation of air pollution tolerance index, we used the following formula (Prajapati and Tripathi 2008):

$\mathrm{APTI}=\frac{A \times(T+P)+R}{10}$,

where $A$ is the ascorbic acid content in leaves $\left(\mathrm{mg} \mathrm{g}^{-1}\right.$ fresh weight), $T$ the total leaf chlorophyll contents $\left(\mathrm{mg} \mathrm{g}^{-1}\right.$ fresh weight), $P$ the $\mathrm{pH}$ of leaves' extract and $R$ the relative water content $(\%)$.

\section{Statistical Assessment}

All statistical calculation was performed by using the Statistical Program (Statistica version 10, StatSoft Inc.). The observations were replicated five times for each parameter, the mean standard error was calculated and the values were polled. In this study, the significant statistical differences were estimated by Tukey's test. The Pearson coefficient of correlation for assessing the estimated parameters was also calculated. Analysis of variance (ANOVA) helped to determine the variables of concentrations that are significantly different in soil and plant material from the stands investigated.

\section{Results}

\section{Soil Analysis}

The study on selected stands within the city of Sosnowiec shows that the average level of organic matter accounted for $14.17 \%$. Low contents were found only at the expressway, Cedler and Kukułki stands. The $\mathrm{pH}$ of the soil ranged from 6.97 to 8.96, and most of the stands tested had $\mathrm{pH}$ higher than 7. Neutral pH was observed in soil samples collected at the Kukułki stand, and highly alkaline $\mathrm{pH}$ at the expressway stand (Table 1).

Analysis of the soil material's carbon content showed an average value of $7.07 \%$. The highest concentrations were recorded at the Las $(14.9 \%)$ and Juliusz (11\%) stands. Significantly low levels of $\mathrm{C}$ were found at Kukulki (2.6\%). Examination of the soil material's nitrogen content showed a mean value of $0.74 \%$. The highest concentration was recorded at the Las stand $(1 \%)$. The soil material demonstrated an average sulphur content of $0.88 \%$. The highest concentrations were recorded at the Juliusz $(0.20 \%)$ and Las stands $(0.11 \%)$. A significantly low concentration 
Table 1 Soil analysis of Sosnowiec

\begin{tabular}{llcccc}
\hline Stands & $\mathrm{pH}$ & Organic matter, \% & $C, \%$ & $N, \%$ & \multicolumn{1}{c}{$S, \%$} \\
\hline Expressway & $8.96 \pm 0.23 \mathrm{abc}$ & $7.19 \pm 0.52 \mathrm{ab}$ & $3.59 \pm 0.09 \mathrm{a}$ & $0.70 \pm 0.05 \mathrm{a}$ & $0.04 \pm 0.03 \mathrm{ab}$ \\
Buczek & $7.44 \pm 0.08 \mathrm{ab}$ & $11.53 \pm 0.11 \mathrm{ab}$ & $5.18 \pm 0.12 \mathrm{ab}$ & $0.77 \pm 0.03 \mathrm{a}$ & $0.05 \pm 0.02 \mathrm{abc}$ \\
KWK & $7.43 \pm 0.02 \mathrm{ab}$ & $12.48 \pm 1.83 \mathrm{ab}$ & $8 \pm 0.27 \mathrm{~b}$ & $0.68 \pm 0.03 \mathrm{a}$ & $0.11 \pm 0.071 \mathrm{abc}$ \\
Cedler & $7.49 \pm 0.06 \mathrm{ab}$ & $7.6 \pm 0.91 \mathrm{ab}$ & $4.32 \pm 0.08 \mathrm{ab}$ & $0.63 \pm 0.04 \mathrm{a}$ & $0.05 \pm 0.041 \mathrm{ab}$ \\
Juliusz & $7.75 \pm 0.02 \mathrm{ab}$ & $21.26 \pm 2.80 \mathrm{bc}$ & $11.60 \pm 0.56 \mathrm{bc}$ & $0.65 \pm 0.02 \mathrm{a}$ & $0.12 \pm 0.03 \mathrm{c}$ \\
Sokolska & $7.83 \pm 0.08 \mathrm{ab}$ & $12.84 \pm 0.49 \mathrm{ab}$ & $5.47 \pm 0.37 \mathrm{ab}$ & $0.73 \pm 0.06 \mathrm{a}$ & $0.05 \pm 0.05 \mathrm{abc}$ \\
Zagórze & $7.55 \pm 0.06 \mathrm{ab}$ & $19.12 \pm 2.17 \mathrm{bc}$ & $7.76 \pm 0.74 \mathrm{~b}$ & $0.92 \pm 0.01 \mathrm{a}$ & $0.12 \pm 0.06 \mathrm{abc}$ \\
Kukulki & $6.97 \pm 0.09 \mathrm{ab}$ & $4.613 \pm 0.20 \mathrm{a}$ & $2.64 \pm 0.33 \mathrm{a}$ & $0.63 \pm 0.03 \mathrm{a}$ & $0.01 \pm 0.04 \mathrm{a}$ \\
Las & $8 \pm 0.04 \mathrm{ab}$ & $32.66 \pm 1.48 \mathrm{c}$ & $14.94 \pm 2.98 \mathrm{c}$ & $1.09 \pm 0.05 \mathrm{a}$ & $0.14 \pm 0.01 \mathrm{bc}$ \\
Klimontów & $7.65 \pm 0.07 \mathrm{ab}$ & $12.43 \pm 0.91 \mathrm{bc}$ & $7.18 \pm 1.01 \mathrm{ab}$ & $0.58 \pm 0.04 \mathrm{a}$ & $0.08 \pm 0.04 \mathrm{abc}$ \\
\hline
\end{tabular}

of sulphur was recorded at the Kukułki (0.02\%) stand (Table 1).

The metal content fraction after extraction of $10 \%$ $\mathrm{HNO}_{3}$ acid in the top layer of soil in the city of Sosnowiec shows that the content of $\mathrm{Pb}$ in the study area was between 44.9 and $762 \mathrm{mg} \mathrm{kg}^{-1}$. The Cedler stand showed that the concentration of $\mathrm{Pb}$ exceeded the permissible concentration by more than seven times. Concentration of $\mathrm{Pb}$ above the average for the city was recorded at the Buczek, Juliusz, Sokolska, Zagórze, Las and Klimontów stands (Table 2). In the study area, the highest concentration of zinc (200.82 $\mathrm{mg} \mathrm{kg}^{-1}$ ) was observed in the soil from the Cedler stand, and the lowest from the KWK stand (113.5 $\mathrm{mg} \mathrm{kg}^{-1}$ ); the average was $141 \mathrm{mg} \mathrm{kg}^{-1}$. Aboveaverage $\mathrm{Zn}$ content was noticed at the Cedler, Las and Klimontów stands (Table 2). The iron content in the soil in Sosnowiec was in the range of $535-6056 \mathrm{mg} \mathrm{kg}^{-1}$. The average concentration was recorded at $1591 \mathrm{mg} \mathrm{kg}^{-1}$. The lowest levels were observed at the KWK and Kukułki stands. The iron content at the Buczek, Juliusz, Zagórze and Las stands exhibited similar results (Table 2). The cadmium content in the soil in the city of Sosnowiec was $1.46-58.8 \mathrm{mg} \mathrm{kg}^{-1}$. The limit values for cadmium (3 $\mathrm{mg} \mathrm{kg}^{-1}$ ) were exceeded at almost all the stands (Buczek, Cedler, Sokolska, Zagórze, Kukułki, Las, Klimontów). The highest concentration was observed at the Cedler stand (58.8 $\mathrm{mg} \mathrm{kg}^{-1}$ ), which is almost 20 times higher than the norm. The lowest concentration was characteristic of soil from the KWK and Julius stands, at an average of $10.42 \mathrm{mg} \mathrm{kg}^{-1}$ (Table 2).

\section{Analysis of Plant Material}

The $\mathrm{Pb}$ content in the study area ranged from 3.5 to $32.4 \mathrm{mg} \mathrm{kg}^{-1}$. At the KWK (coal mine) stand, the leaf of $P$. lanceolata showed that the concentration

Table 2 Metal content in the soil of Sosnowiec

\begin{tabular}{lcccrr}
\hline Stands & $\mathrm{Cd}, \mathrm{mg} \mathrm{kg}^{-1}$ & $\mathrm{~Pb}, \mathrm{mg} \mathrm{kg}^{-1}$ & $\mathrm{Zn}, \mathrm{mg} \mathrm{kg}^{-1}$ & $\mathrm{Fe}, \mathrm{mg} \mathrm{kg}^{-1}$ & ${\mathrm{Mn}, \mathrm{mg} \mathrm{kg}^{-1}}$ \\
\hline Expressway & $2.87 \pm 0.15 \mathrm{a}$ & $90.97 \pm 11.32 \mathrm{a}$ & $126.03 \pm 10.9 \mathrm{ab}$ & $959.9 \pm 57 \mathrm{~b}$ & $120.53 \pm 11.7 \mathrm{a}$ \\
Buczek & $3.38 \pm 0.39 \mathrm{ab}$ & $149.54 \pm 19.8 \mathrm{~b}$ & $124.07 \pm 13.7 \mathrm{ab}$ & $1326.85 \pm 87.3 \mathrm{bc}$ & $336.68 \pm 35.7 \mathrm{bc}$ \\
KWK & $1.46 \pm 0.09 \mathrm{a}$ & $44.96 \pm 8.42 \mathrm{a}$ & $113.57 \pm 5.21 \mathrm{ab}$ & $855.52 \pm 36.9 \mathrm{~b}$ & $229.3 \pm 17.1 \mathrm{~b}$ \\
Cedler & $58.82 \pm 2.76 \mathrm{~d}$ & $762.6 \pm 37.3 \mathrm{~d}$ & $200.82 \pm 14.7 \mathrm{c}$ & $6056.6 \pm 132 \mathrm{~d}$ & $1304.72 \pm 113.6 \mathrm{~d}$ \\
Juliusz & $1.61 \pm 0.5 \mathrm{a}$ & $179.26 \pm 26.3 \mathrm{~b}$ & $132.7 \pm 8.47 \mathrm{ab}$ & $1347.93 \pm 45.9 \mathrm{bc}$ & $326.96 \pm 5.72 \mathrm{bc}$ \\
Sokolska & $7.59 \pm 1.02 \mathrm{bc}$ & $218.88 \pm 40.1 \mathrm{bc}$ & $138.17 \pm 12.33 \mathrm{~b}$ & $953.84 \pm 41.2 \mathrm{~b}$ & $259.91 \pm 16.6 \mathrm{~b}$ \\
Zagórze & $5.88 \pm 0.63 \mathrm{~b}$ & $179.04 \pm 9.31 \mathrm{bc}$ & $138.55 \pm 3.54 \mathrm{~b}$ & $1334.03 \pm 71.8 \mathrm{bc}$ & $376.15 \pm 14.1 \mathrm{c}$ \\
Kukulki & $4.38 \pm 0.45 \mathrm{~b}$ & $92.48 \pm 15.3 \mathrm{a}$ & $118.55 \pm 9.09 \mathrm{a}$ & $535.15 \pm 21.6 \mathrm{a}$ & $210.92 \pm 21.3 \mathrm{ab}$ \\
Las & $12.52 \pm 1.8 \mathrm{bc}$ & $277.31 \pm 18.5 \mathrm{c}$ & $164.67 \pm 15.5 \mathrm{bc}$ & $1351.15 \pm 35.9 \mathrm{bc}$ & $508.14 \pm 15.7 \mathrm{c}$ \\
Klimontów & $5.71 \pm 0.44 \mathrm{~b}$ & $153.99 \pm 10.7 \mathrm{~b}$ & $155.9 \pm 8.97 \mathrm{~b}$ & $1196.64 \pm 66.2 \mathrm{bc}$ & $250.95 \pm 6.85 \mathrm{ab}$
\end{tabular}

Data expressed as mean \pm SD

$\mathrm{a}-\mathrm{d}-$ medians followed by the same letter are not significantly different between particular metal concentrations in the fraction extracted with $\mathrm{HNO}_{3}$ and organic matter content, $\mathrm{C}, \mathrm{N}, \mathrm{S}$ content, $\mathrm{pH}$ values, $(p<0.05)$ 
(32.4 $\mathrm{mg} \mathrm{kg}^{-1}$ ) exceeded the allowable level of $30 \mathrm{mg} \mathrm{kg}^{-1}$. Above-average concentrations of $\mathrm{Pb}$ for the city were recorded at the Buczek, Sokolska and Klimontów stands (Table 3). In the study area, the highest concentration of zinc ( $129.78 \mathrm{mg} \mathrm{kg}^{-1}$ ) was found in the leaves of $P$. major at the Las Kazimierz stand; the average was $58.8 \mathrm{mg} \mathrm{kg}^{-1}$ for $P$. major and $48 \mathrm{mg} \mathrm{kg}^{-1}$ for $P$. lanceolata (Table 3 ). The range of manganese content in Sosnowiec was $6.2-41.7 \mathrm{mg} \mathrm{kg}^{-1}$. The highest concentration was recorded at the Las stand $\left(41.7 \mathrm{mg} \mathrm{kg}^{-1}\right)$ with an average content of $16.9 \mathrm{mg} \mathrm{kg}^{-1}$ for $P$. major and $14.14 \mathrm{mg} \mathrm{kg}^{-1}$ for $P$. lanceolata. The lowest concentration was observed in the leaves of $P$. lanceolata at the Buczek and KWK stands (Table 3). The iron content in the study area was in the range of $69.36-308.7 \mathrm{mg} \mathrm{kg}^{-1}$. The highest concentrations were observed at the KWK, Cedler, Zagórze and Klimontów stands. The lowest concentration of iron was noted at the Buczek stand for both leaves of $P$. major (82.9 $\mathrm{mg} \mathrm{kg}^{-1}$ ) and $P$. lanceolata $\left(69.36 \mathrm{mg} \mathrm{kg}^{-1}\right.$ ) (Table 3$)$. In the study area, there were no toxic concentrations of $\mathrm{Cd}\left(5 \mathrm{mg} \mathrm{kg}{ }^{-1}\right)$, and even at the Buczek and KWK stands this element was below the level of apparatus detection for the Plantago species. The range of $\mathrm{Cd}$ was from 0.25 to $4.3 \mathrm{mg} \mathrm{kg}^{-1}$ (Table 3).

A general comparison of the accumulation of selected metals in leaves of the species studied is given in Table 3, and Table 4 shows the data of the biochemical parameters of the species investigated.

To estimate the state of the environment, in addition to the above-mentioned studies, content determination of the total chlorophyll, ascorbic acid, RWC and $\mathrm{pH}$ of the leaves was conducted. The $\mathrm{pH}$ range of the extract from leaves in the study area was 5.26-6.45. The lowest $\mathrm{pH}$ was recorded at the Cedler and Klimontów stands. The average $\mathrm{pH}$ for $P$. major leaves was 5.59, which is similar to the average of $P$. lanceolata (5.76), A. millefolium (5.9) and $R$. pseudoacacia (6.18) (Table 4). In the calculation of the RWC index, it was found that relatively average water content in the leaves of $P$. major accounted for nearly $72 \%$, and for $P$. lanceolata $80.4 \%$, A. millefolium $71 \%$ and $R$. pseudoacacia $76 \%$, which testifies to the resistance of the selected plants to water stress. The KWK, Sokolska and Kukulki stands had the lowest RWC values (Table 4). Both the highest and the lowest values of the total chlorophyll content stand were noted in the area of the 'polluted' KWK stand $(0.18$ and $1.27 \mathrm{mg} \mathrm{g}^{-1}$ f.w.) in the Plantago species. The average total chlorophyll content in the leaves of $P$. major and $P$. lanceolata was 0.63 and $0.68 \mathrm{mg} \mathrm{g}^{-1}$ f.w. respectively, $0.18 \mathrm{mg} \mathrm{g}^{-1}$ f.w. in A. millefolium and $0.33 \mathrm{mg} \mathrm{g}^{-1}$ f.w. in R. pseudoacacia (Table 4). The highest concentration of ascorbic acid was reported at the 'clean' Las Kazimierz stand in $P$. lanceolata, $0.62 \mathrm{mg} \mathrm{g}^{-1} \mathrm{f} . \mathrm{w}$. The average content of ascorbic acid in the leaves of $P$. major was
$0.19 \mathrm{mg} \mathrm{g}^{-1}$ f.w., $0.26 \mathrm{mg} \mathrm{g}^{-1}$ f.w. for the P. lanceolata leaf, $0.26 \mathrm{mg} \mathrm{g}^{-1}$ f.w. for A. millefolium and $0.26 \mathrm{mg} \mathrm{g}^{-1}$ f.w. for $R$. pseudoacacia (Table 4).

All of the above indicators were needed to calculate the air pollution tolerance index, which represents the plants' tolerance to air pollution. For the species of plants studied in the city of Sosnowiec, the air pollution tolerance index ranged from 4.4 to 9.42 . $P$. lanceolata was characterised by an average 7.78, higher than that of P. major (7.17), A. millefolium (7.22) and $R$. pseudoacacia (7.16) (see Table 5). The air pollution tolerance index was lowest at the Kukułki stand.

\section{Statistical Analysis}

Significant positive correlation coefficients were found in the soil samples between the content of $\mathrm{C}$ and the contents of $\mathrm{N}$ and $\mathrm{S}(r=0.62 ; r=0.94)$. For $P$. major, a clear correlation was found between the concentration of relative water content, the $\mathrm{pH}$ value and the content of $\mathrm{Cd}$ ( $r=-0.71$ and $r=0.73$ respectively) and between the concentration of ascorbic acid and the content of $\mathrm{Zn}$ $(r=-0.6)$. For P. lanceolata, a clear correlation was also found between the concentration of chlorophyll and the content of $\mathrm{Fe}(r=0.57)$. A correlation between the concentration of chlorophyll, ascorbic acid and the content of $\mathrm{Pb}(r=0.57 ; r=-0.51)$, and the correlation between concentration of ascorbic acid, relative water content and Cd concentration $(r=0.83 ; r=-0.83)$ was also found. For A. millefolium, negative values of the correlation index were also noted between $\mathrm{Fe}$ and $\mathrm{Mn}$ elements and the $\mathrm{pH}$ of the leaves $A$. millefolium ( $r=-0.56 ; r=-0.63$ ). For $R$. pseudoacacia significant positive correlation coefficients were found between the $\mathrm{pH}$ and the content of $\mathrm{Mn}$ $(r=0.51)$.

\section{Discussion}

The choice of Sosnowiec as the location for environmental studies proved to be very appropriate. On the one hand, as a highly urbanised city it provides information on the impact of pollution on the natural environment associated with industrialisation; on the other hand, the in-depth analysis of the individual components of the urban ecosystem revealed its actual condition. The areas of research we selected allowed the verification of the degree of element contamination in areas related to industry compared to the potentially clean areas of Sosnowiec.

The study of soil material confirmed that the greatest problem is soil pollution by lead and cadmium caused by emissions from industrial plants. At present, they are relatively small and do not cause high-intensity polluted 


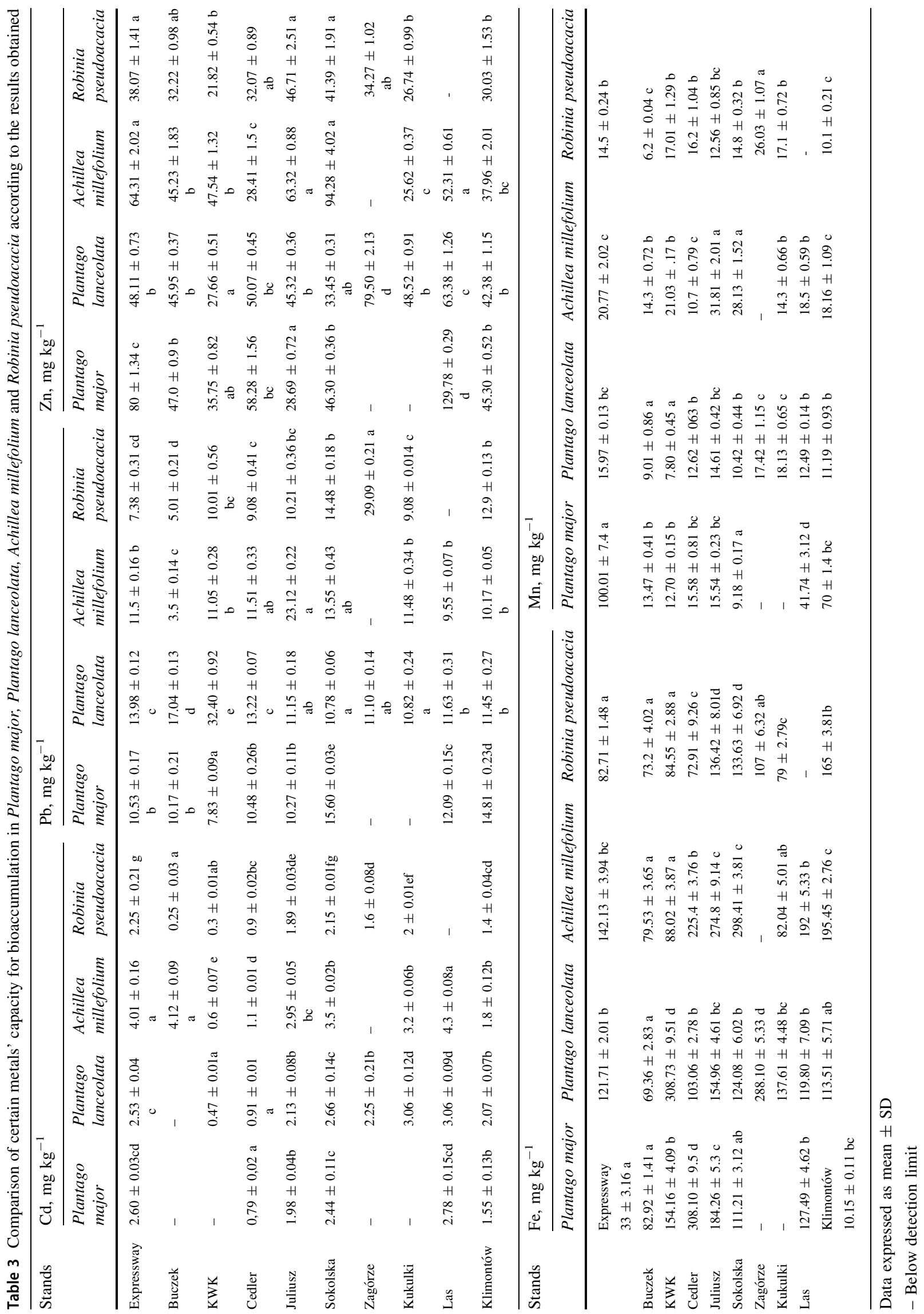


Table 4 Comparison of biochemical parameters of Plantago major, Plantago lanceolata, Achillea millefolium and Robinia pseudoacacia according to the results obtained

\begin{tabular}{|c|c|c|c|c|}
\hline \multirow[t]{2}{*}{ Stands } & \multicolumn{4}{|l|}{$\mathrm{pH}$} \\
\hline & Plantago major & Plantago lanceolata & Achillea millefolium & Robinia pseudoacacia \\
\hline Expressway & $5.73 \pm 0.04 \mathrm{~d}$ & $5.8 \pm 0.05 \mathrm{c}$ & $6.15 \pm 0.12 \mathrm{~cd}$ & $6.45 \pm 0.09 \mathrm{e}$ \\
\hline Buczek & $5.61 \pm 0.06 \mathrm{c}$ & $5.74 \pm 0.13 b$ & $6.15 \pm 0.15 \mathrm{c}$ & $6.2 \pm 0.11 \mathrm{~cd}$ \\
\hline KWK & $5.79 \pm 0.02 \mathrm{~d}$ & $5.78 \pm 0.21 \mathrm{~b}$ & $6.1 \pm 0.06 \mathrm{c}$ & $6.19 \pm 0.14 \mathrm{~cd}$ \\
\hline Cedler & $5.42 \pm 0.01 \mathrm{~b}$ & $5.65 \pm 0.08 \mathrm{a}$ & $6.19 \pm 0.12 \mathrm{~cd}$ & $6.2 \pm 0.21 \mathrm{~cd}$ \\
\hline Juliusz & $5.63 \pm 0.12 \mathrm{c}$ & $5.85 \pm 0.37 \mathrm{ab}$ & $5.7 \pm 0.17 \mathrm{a}$ & $6.27 \pm 0.18 \mathrm{~d}$ \\
\hline Sokolska & $5.69 \pm 0.07 \mathrm{c}$ & $5.73 \pm 0.04 \mathrm{a}$ & $6.08 \pm 0.08 \mathrm{c}$ & $6.11 \pm 0.1 \mathrm{~cd}$ \\
\hline Zagórze & - & $5.79 \pm 0.11 \mathrm{ab}$ & - & $6.22 \pm 0.03 \mathrm{~cd}$ \\
\hline Kukulki & - & $5.89 \pm 0.05 \mathrm{c}$ & $6.2 \pm 0.21 \mathrm{~cd}$ & $6.3 \pm 0.13 \mathrm{~d}$ \\
\hline Las & $5.6 \pm 0.12 \mathrm{c}$ & $5.8 \pm 0.03 \mathrm{c}$ & $5.9 \pm 0.13 \mathrm{~b}$ & - \\
\hline Klimontów & $5.26 \pm 0.03 \mathrm{a}$ & $5.66 \pm 0.15 \mathrm{a}$ & $6.01 \pm 0.05 \mathrm{bc}$ & $6.33 \pm 0.122 \mathrm{e}$ \\
\hline \multirow[t]{2}{*}{ Stands } & \multicolumn{4}{|l|}{ RWC, \% } \\
\hline & Plantago major & Plantago lanceolata & Achillea millefolium & Robinia pseudoacacia \\
\hline Expressway & $79.07 \pm 3.07 \mathrm{de}$ & $75.23 \pm 5.91 \mathrm{bc}$ & $93.45 \pm 2.19 \mathrm{~d}$ & $75.08 \pm 1.78 \mathrm{c}$ \\
\hline Buczek & $84.56 \pm 4.45 \mathrm{e}$ & $87.97 \pm 2.3 \mathrm{c}$ & $76.69 \pm 1.51 \mathrm{bc}$ & $72.89 \pm 3.63 \mathrm{c}$ \\
\hline KWK & $46.79 \pm 4.11 \mathrm{a}$ & $92.19 \pm 6.31 \mathrm{~d}$ & $87.65 \pm 4.88 \mathrm{c}$ & $46.83 \pm 1.75 \mathrm{a}$ \\
\hline Cedler & $88.06 \pm 5.71 \mathrm{e}$ & $85.08 \pm 6.22 \mathrm{c}$ & $82.78 \pm 2.91 \mathrm{c}$ & $91.95 \pm 5.655 \mathrm{~d}$ \\
\hline Juliusz & $71.84 \pm 5.03 \mathrm{~d}$ & $87.71 \pm 5.89 \mathrm{c}$ & $60.10 \pm 3.04 \mathrm{~b}$ & $74.89 \pm 3.94 \mathrm{c}$ \\
\hline Sokolska & $56.19 \pm 4.21 \mathrm{~b}$ & $60.36 \pm 1.91 \mathrm{ab}$ & $71.20 \pm 6.91 \mathrm{bc}$ & $65.66 \pm 4.09 \mathrm{~b}$ \\
\hline Zagórze & - & $91.49 \pm 3.88 \mathrm{~d}$ & - & $68.29 \pm 1.02 \mathrm{~b}$ \\
\hline Kukulki & - & $51.76 \pm 2.05 \mathrm{a}$ & $43.80 \pm 1.35 \mathrm{a}$ & $72.73 \pm 4.14 \mathrm{c}$ \\
\hline Las & $66.11 \pm 2.55 \mathrm{c}$ & $89.69 \pm 5.23 \mathrm{~d}$ & $49.74 \pm 2.04 \mathrm{a}$ & - \\
\hline Klimontów & $80.85 \pm 3.48 \mathrm{de}$ & $82.70 \pm 4.87 \mathrm{c}$ & $82.81 \pm 3.41 \mathrm{c}$ & $71.36 \pm 2.08 \mathrm{c}$ \\
\hline \multirow[t]{2}{*}{ Stands } & \multicolumn{4}{|c|}{ Ascorbic acid content, $\mathrm{mg} \mathrm{g}^{-1}$ f.w. } \\
\hline & Plantago major & Plantago lanceolata & Achillea millefolium & Robinia pseudoacacia \\
\hline Expressway & $0.05 \pm 0.01 \mathrm{a}$ & $0.36 \pm 0.01 \mathrm{c}$ & $0.12 \pm 0.01 \mathrm{e}$ & $0.52 \pm 0.01 \mathrm{bc}$ \\
\hline Buczek & $0.04 \pm 0.01 \mathrm{a}$ & $0.19 \pm 0.01 \mathrm{~b}$ & $0.01 \pm 0.01 \mathrm{a}$ & $0.059 \pm 0.01 \mathrm{c}$ \\
\hline KWK & $0.21 \pm 0.01 \mathrm{c}$ & $0.03 \pm 0.01 \mathrm{a}$ & $0.02 \pm 0.01 \mathrm{~b}$ & $0.03 \pm 0.01 \mathrm{ab}$ \\
\hline Cedler & $0.18 \pm 0.01 \mathrm{bc}$ & $0.03 \pm 0.01 \mathrm{a}$ & $0.036 \pm 0.01 \mathrm{~d}$ & $0.018 \pm 0.01 \mathrm{a}$ \\
\hline Juliusz & $0.30 \pm 0.01 \mathrm{c}$ & $0.19 \pm 0.01 \mathrm{~b}$ & $0.034 \pm 0.01 \mathrm{~cd}$ & $0.033 \pm 0.01 \mathrm{~b}$ \\
\hline Sokolska & $0.34 \pm 0.01 \mathrm{c}$ & $0.36 \pm 0.01 \mathrm{c}$ & $0.023 \pm 0.01 \mathrm{~b}$ & $0.057 \pm 0.01 \mathrm{c}$ \\
\hline Zagórze & - & $0.38 \pm 0.01 \mathrm{c}$ & - & $0.035 \pm 0.01 \mathrm{~b}$ \\
\hline Kukulki & - & $0.26 \pm 0.01 \mathrm{bc}$ & $0.028 \pm 0.01 \mathrm{~b}$ & $0.018 \pm 0.01 \mathrm{a}$ \\
\hline Las & $0.19 \pm 0.01 \mathrm{bc}$ & $0.62 \pm 0.01 \mathrm{~d}$ & $0.018 \pm 0.01 \mathrm{~b}$ & - \\
\hline Klimontów & $0.21 \pm 0.01 \mathrm{c}$ & $0.20 \pm 0.01 \mathrm{bc}$ & $0.01 \pm 0.01 \mathrm{a}$ & $0.036 \pm 0.01 \mathrm{~b}$ \\
\hline \multirow[t]{2}{*}{ Stands } & \multicolumn{4}{|c|}{ Total chlorophyll content, $\mathrm{mg} \mathrm{g}^{-1}$ f.w. } \\
\hline & Plantago major & Plantago lanceolata & Achillea millefolium & Robinia pseudoacacia \\
\hline Expressway & $0.74 \pm 0.04 \mathrm{c}$ & $0.71 \pm 0.03 \mathrm{c}$ & $0.27 \pm 0.02 \mathrm{a}$ & $0.38 \pm 0.01 \mathrm{c}$ \\
\hline Buczek & $0.65 \pm 0.05 \mathrm{c}$ & $0.47 \pm 0.01 \mathrm{a}$ & $0.22 \pm 0.01 \mathrm{a}$ & $0.39 \pm 0.02 \mathrm{c}$ \\
\hline KWK & $0.23 \pm 0.01 \mathrm{a}$ & $1.27 \pm 0.03 \mathrm{~d}$ & $0.22 \pm 0.01 \mathrm{a}$ & $0.3 \pm 0.01 \mathrm{bc}$ \\
\hline Cedler & $0.72 \pm 0.02 \mathrm{c}$ & $0.42 \pm 0.02 \mathrm{a}$ & $0.18 \pm 0.01 \mathrm{ab}$ & $0.45 \pm 0.03 \mathrm{c}$ \\
\hline Juliusz & $0.85 \pm 0.04 \mathrm{~d}$ & $0.82 \pm 0.05 \mathrm{c}$ & $0.15 \pm 0.01 \mathrm{ab}$ & $0.33 \pm 0.01 \mathrm{bc}$ \\
\hline Sokolska & $0.92 \pm 0.01 \mathrm{~d}$ & $0.69 \pm 0.04 \mathrm{~b}$ & $0.23 \pm 0.01 \mathrm{~b}$ & $0.68 \pm 0.03 \mathrm{~d}$ \\
\hline Zagórze & - & $0.59 \pm 0.01 \mathrm{~b}$ & - & $0.13 \pm 0.01 \mathrm{ab}$ \\
\hline
\end{tabular}


Table 4 (continued)

\begin{tabular}{lllll}
\hline Stands & \multicolumn{2}{l}{ Total chlorophyll content, $\mathrm{mg} \mathrm{g}^{-1} \mathrm{f} . \mathrm{w}}$. & Robinia pseudoacacia \\
\cline { 2 - 5 } & Plantago major & Plantago lanceolata & Achillea millefolium & $0.08 \pm 0.01 \mathrm{a}$ \\
\hline Kukulki & - & $0.65 \pm 0.02 \mathrm{~b}$ & $0.12 \pm 0.01 \mathrm{bc}$ & - \\
Las & $0.46 \pm 0.01 \mathrm{~b}$ & $0.75 \pm 0.02 \mathrm{c}$ & $0.11 \pm 0.01 \mathrm{bc}$ & $0.27 \pm 0.01 \mathrm{abc}$ \\
Klimontów & $0.49 \pm 0.02 \mathrm{~b}$ & $0.47 \pm 0.01 \mathrm{a}$ & $0.09 \pm 0.01 \mathrm{bc}$ & \\
\hline
\end{tabular}

Data expressed as mean $\pm \mathrm{SD}$

a-d-medians followed by the same letter are not significantly different between particular metal concentrations in the fraction extracted with $\mathrm{HNO}_{3}$ and ascorbic acid content, total chlorophyll content, RWC, $\mathrm{pH}$ values, $(p<0.05)$

rainfall which penetrates the surface. However, heavy metals in soils have a very long period of decay, up to a few hundred years, so the area of the Silesian agglomeration is still characterised by some of the most polluted soils (degree 3 of 5 in the IUNG Environmental Protection Programme for the Province of Silesia to 2019, taking into account prospects for the years 2024, pub. 2015). The soils of the Silesian province are threatened primarily by anthropogenic factors, principally industrial activity, inappropriate farming agricultural practices and the impact of transport. Threats to soil also result from commercial exploitation of minerals and inappropriate waste management, especially in urbanised areas. In Sosnowiec, it has been shown that the standards of acceptable concentrations in soil are exceeded (Regulation by the Minister of Environment 2002), both in terms of $\mathrm{Pb}$ (for most study areas) and $\mathrm{Cd}(60 \%$ of study stands). The highest reported concentrations of these elements were present at the Cedler stand (where they exceeded the limit values in terms of $\mathrm{Pb}$ by 7 times, and in terms of Cd by almost 15 times), which is also characterised by very high contents of the other elements analysed ( $\mathrm{Fe}, \mathrm{Zn}, \mathrm{Mn})$. This situation is associated with more than a 100 years of heavy industrial activity, as well as the presence of mill and brick factories and other businesses in the area studied.

For comparison, in Zabrze (Southern Poland) extremely high concentrations of $\mathrm{Zn}$ were reported, ranging from 31.69 to $2057.16 \mathrm{mg} \mathrm{kg}^{-1}$; $\mathrm{Pb}$ from 31.5 to $520 \mathrm{mg} \mathrm{kg}^{-1}$; and Cd from 1.5 to $13.1 \mathrm{mg} \mathrm{kg}^{-1}$. It was also noted that the highest $\mathrm{Zn}, \mathrm{Pb}$, and $\mathrm{Cd}$ concentrations were recorded near defunct smelter landfills and in the vicinity of roads (Kandziora-Ciupa et al. 2013). Our results also show that the highest levels of metal accumulation were found in the area of industrial plants, especially at the Cedler stand (currently a metallurgical plant) where the highest concentrations of $\mathrm{Cd}, \mathrm{Zn}, \mathrm{Pb}, \mathrm{Fe}$ and $\mathrm{Mn}$ in topsoil were recorded. Other studies around the Silesian region demonstrated lower levels of trace element content (Pasieczna 2003).
The highest content of organic matter was noted in the topsoil at the Las stand (c. 32\%) and the average value in Sosnowiec was $14 \%$. Both these factors-the high $\mathrm{pH}$ and the relatively large contents of organic matter-may be the reason for the demonstrated low levels of metals in bioavailable forms and the increased creation of organometallic complexes in the soil. The cause of this phenomenon is the inhibition of uptake by plant ions of heavy metals, resulting in the detoxification of the soil complex (Kwiatkowska-Malina and Maciejewska 2009).

The $\mathrm{pH}$ value of the soil affects the bioavailability of nutrients for plants in this way; too high a value results in reduced solubility and the absorption of many elements, and may cause the precipitation of different compounds. The studies of the soil's $\mathrm{pH}$ index show an alkaline and neutral nature (Table 1). The only exception was the Kukułki stand where the $\mathrm{pH}$ value was 6.97 , which is near neutral value. On the other hand, the studies of the leaves' $\mathrm{pH}$ show an acidic nature within the range of 5.26 to 6.45 ; the highest $\mathrm{pH}$ value was noticed at the expressway stand in the R. pseudoacacia leaves.

Research into the bioaccumulation of metals has identified P. major and P. lanceolata as good bioindicators of environmental pollution by selected heavy metals (GucwaPrzepióra et al. 2016; Kurteva 2009; Nadgórska-Socha et al. 2013a, b). In the present work, excessive concentrations in the toxic range for plants were only found in two cases: $10 \%$ of $\mathrm{Pb}$ and $30 \%$ of $\mathrm{Zn}$. Accordingly, the ranges of background toxicity of small elements in plants are $\mathrm{Pb}$ 30-300 mg kg ${ }^{-1}$ and Zn 100-400 mg kg${ }^{-1}$ (NadgórskaSocha et al. 2013a, b; Kabata-Pendias and Pendias 2001). It was also noted that certain species, such as $P$. major, have the potential for soil phytostabilisation (Romeh and Khamis 2016).

The highest zinc content was demonstrated in the leaves of $P$. major, which may indicate that the metal is extracted in the form of hydrated ions (Gruca-Królikowska and Wacławek 2006). However, overall the leaves of $P$. lanceolata showed a higher concentration of heavy metals 
in comparison to P. major. The lead content in P. lanceolata in the areas analysed are much higher than the results obtained before (Jankowska et al. 2007) for the same species in the vicinity of the highways. It can therefore be assumed that the the automotive industry has much less impact on lead contamination than the long-term impact of industrial emissions. For example, cadmium can be directly taken up by plants through their leaves, in proportion to the concentrations of metals in the air or falling dust (KabataPendias and Pendias 2001).

In the present studies, $R$. pseudoacacia shows lower levels of $\mathrm{Cd}, \mathrm{Zn}$ and $\mathrm{Mn}$ accumulation compared to the results of the other species investigated. Also, lower contents of $\mathrm{Zn}, \mathrm{Cd}, \mathrm{Mn}, \mathrm{Fe}$ and $\mathrm{Pb}$ by two to three times were reported in $R$. pseudoacacia compared to Melandrium album, but at the same time $R$. pseudoacacia presented better capability for $\mathrm{Cu}$ accumulation (Nadgórska-Socha et al. 2016).

The greatest ability to accumulate $\mathrm{Cd}$ was noticed in leaves of A. millefolium. This latter is also well known as a kind of medical plant and demonstrates good morphological and physiological responses to heavy metal pollution, and for these reasons it can be utilised as a bioindicator (Radulescu et al. 2013).

Air pollution has a significant impact on the behaviour of the physiological state of plants, especially chlorophyll, which determines the activity of photosynthesis, growth and growth biomass. The studies on chlorophyll content obtained similar results for $P$. major and $P$. lanceolata; only the contents of total chlorophyll in the leaves of $P$. major at the KWK stand stood out from the rest. A. millefolium and R. pseudoacacia showed a lower level of total chlorophyll content compared to the investigated Plantago species, and the lowest content was noticed at the Kukulki stand in the R. pseudoacacia leaves.

The relative water content of the plants investigated was in the range $43.8-99.45 \%$, and indicates that the selected plant species are not susceptible to water stress. Also, according to the results of the Parthenium hysterophorus study, the high total chlorophyll content might be a reason for its speedy growth, and the relative water content is more connected to managing its survival in a hostile environment (Krishnaveni 2013).

Another important indicator for the physiological condition of the plant is the content of ascorbic acid, which is a strong reducing agent and activates many defence mechanisms in plants. It is located mainly in the chloroplast and plays an important role in the synthesis of cell walls, cell division and the processes associated with the detoxification of the plant (Ogunkunle et al. 2015). Very small quantities of ascorbic acid were indicated at the contaminated sites for all the species investigated, and the highest concentration was noted at the Las Kazimierz stand. The 
pollution load dependent on the increase in the ascorbic acid content of all the plant species might be due to the increased rate of production of reactive oxygen species, as reported by Tripathi and Gautam (2007). Moreover, some research showed high concentrations of ascorbic acid in industrial samples (Agbaire 2009; Meerabai et al. 2012; Rai and Panda 2014).

For P. major, P. lanceolata, A. millefolium and $R$. pseudoacacia in the study area, the air pollution tolerance index range was 4.4-9.42. Low values of air pollution tolerance index were noted for both types of stands, contaminated and conventionally clean. The highest results were obtained for leaves at the expressway, KWK and Las stands. Another study in Southern Poland (Miasteczko Śląskie, Dąbrowa Górnicza, Jaroszowiec) of $R$. pseudoacacia and $M$. album on heavy metal-contaminated sites in comparison with non-contaminated sites presents the mean air pollution tolerance index values for all sites investigated of 9.4 and 8.7 for $R$. pseudoacacia and M. album, respectively. In these two species, the air pollution tolerance index values were higher in the non-contaminated site in comparison with the contaminated sites (Nadgórska-Socha et al. 2016).

The calculation of air pollution tolerance index has been widely investigated by numerous studies around the world. According to Chinese researchers (Zhang et al. 2016), among 47 investigated species collected from two heavy traffic roadside sites and one suburban site in Beijing, the plant species Magnolia denudata, Diospyros kaki, Ailanthus altissima, Fraxinus chinensis and Rosa chinensis were identified as tolerant species to an environment of heavy air pollution and were recommend to be planted at various locations in the city, especially at roadsides experiencing heavy traffic. Studies which were carried out at increasing distances of 100, 300 and $500 \mathrm{~m}$ around three brick kiln sites (Pakistan) showed various air pollution tolerance index (APTI) values of plant species investigated there: Calotropis procera $(\mathrm{APTI}=20.05)$ and Alternanthera pungens $(\mathrm{APTI}=17.13$ ) were found to be the most tolerant species and Malva neglecta (APTI = 8.83) was found to be the most sensitive species (Achakzai et al. 2017). These studies also represent a positive correlation between air pollution tolerance index and ascorbic acid and relative water content.

The air pollution tolerance index allows us to determine not only the general tolerance of plants to pollution, but also to find out the biochemical parameters which are responsible for resistance to the environmental stress factors. The plant species with the higher air pollution tolerance index value can be given priority for plantation programmes in urban and industrial areas, so as to reduce the effects of air pollution and to make the ambient atmosphere clean and healthy (Sisodia and Dutta 2016).
The plant species with lower air pollution tolerance index values can be recommended as bioindicators and suggested for environmental monitoring (Nadgórska-Socha et al. 2016). Thanks to the results obtained, all the species investigated were determined as sensitive and may be recommended for bioindicative research in urban areas.

\section{Conclusions}

The results of the present study revealed that environmental pollution had a substantial impact on the various biochemical parameters. Surprisingly, sites previously described as potentially 'clean' (Zagórze, Las, Kukulki, Klimontów, Sokolska) had similar levels of pollution in comparison to the sites with high levels of anthropogenic load (expressway, KWK, Julius, Cedler, Buczek). This may have been caused by low-stack emission and parking lots near the recreation sites, etc., confirming that pollution is not confined to specific sites associated with industrial activity or high traffic.

The metal content analysis of the soil samples demonstrated that the highest concentrations in Sosnowiec were for $\mathrm{Pb}-762.6 \mathrm{mg} \mathrm{kg}^{-1} ; \mathrm{Mn}-1304 \mathrm{mg} \mathrm{kg}^{-1} ; \mathrm{Zn}-$ $200.8 \mathrm{mg} \mathrm{kg}^{-1}$; $\mathrm{Cd}-58.8 \mathrm{mg} \mathrm{kg}^{-1}$. The maximum permissible concentrations of $\mathrm{Pb}$ and $\mathrm{Cd}$ in the soil (100 $\mathrm{mg} \mathrm{kg}^{-1}$ and $4 \mathrm{mg} \mathrm{kg}^{-1}$, respectively) were exceeded at the stand Cedler (current smelter). However, the range of toxicity adopted for the plants was exceeded for $\mathrm{Zn}$ and $\mathrm{Pb}$ (100-400 and 30-300 $\mathrm{mg} \mathrm{kg}^{-1}$, respectively) only at two stands: KWK Sosnowiec (fomer coal mine) and Las Kazimierz (forest-a recreational area).

The statistical analysis demonstrated strong correlation between the concentration of ascorbic acid, relative water content, the $\mathrm{pH}$ value and the cadmium content for Plantago species, although A. millefolium demonstrated the highest $\mathrm{Cd}$ accumulation ability. P. lanceolata, $P$. major, A. millefolium and $R$. pseudoacacia were found to be tolerant to contamination. The air pollution tolerance index (4.4-9.42) demonstrated that the studied species were sensitive to air pollution, including heavy metals, and hence suggests their use as bioindicators of the state of the environment. In addition, the studied species can be incorporated into greenbelts to assist the environmental policy and management practices in urban industrial areas. Therefore, it is important to continue this type of research on plants for better understanding of interactions and correlations between environmental pollution and various ecological, biochemical, and physiological parameters in urban industrial environments. 


\section{Compliance with Ethical Standards}

Conflict of interest The authors declare that they have no conflict of interest.

Open Access This article is distributed under the terms of the Creative Commons Attribution 4.0 International License (http://creative commons.org/licenses/by/4.0/), which permits unrestricted use, distribution, and reproduction in any medium, provided you give appropriate credit to the original author(s) and the source, provide a link to the Creative Commons license, and indicate if changes were made.

\section{References}

Abida B, Harikrishna S (2010) Evaluation of some tree species to absorb air pollutants in three industrial locations of South Bengaluru, India. E-J Chem 7(S1):151-156. https://doi.org/10. 1155/2010/398382

Achakzai K, Khalid S, Adrees M, Bibi A, Ali S, Nawaz R, Rizwan M (2017) Air pollution tolerance index of plants around brick kilns in Rawalpindi, Pakistan. J Environ Manag 190(2017):252-258. https://doi.org/10.1016/j.jenvman.2016.12.072

Agbaire P, Esiefarienrhe E (2009) Air pollution tolerance indices (APTI) of some plants around otorogun gas plant in delta state, Nigeria. J Appl Sci Environ Manag 13(1):11-14. https://doi.org/ 10.5897/AJB2014.13616

Arnon D (1949) Copper enzymes in isolated chloroplast: polyphenol oxidase in Beta vulgaris. Plant Physiol 24:1-15

Dao L, Morrison L, Zhang H, Zhang C (2014) Influences of traffic on $\mathrm{Pb}, \mathrm{Cu}$ and $\mathrm{Zn}$ concentrations in roadside soils of an urban park in Dublin, Ireland. Environ Geochem Health 36:333-343. https://doi.org/10.1007/s10653-013-9553-8

Dassonville N, Vanderhoeven S, Vanparys V, Hayez M, Gruber W, Meerts P (2008) Impacts of alien invasive plants on soil nutrients are correlated with initial site conditions in NW Europe. Oecologia 157:131-140. https://doi.org/10.1007/s00442-0081054-6

Dziubanek G, Piekut A, Rusin M, Baranowska M, Hajok I (2015) Contamination of food crops grown on soils with elevated heavy metals content. Ecotoxicol Environ Saf 118:183-189

Elnazer A, Salman S, Seleem E, Abu El Ella E (2015) Assessment of some heavy metals pollution and bioavailability in roadside soil of Alexandria-Marsa Matruh Highway, Egypt. Hindawi Publishing Corporation. Int J Ecol 2015, Article ID 689420. http:// dx.doi.org/10.1155/2015/689420

Gucwa-Przepióra E, Nadgórska-Socha A, Fojcik B, Chmura D (2016) Enzymatic activities and arbuscular mycorrhizal colonization of Plantago lanceolata and Plantago major in a soil root zone under heavy metal stress. Environ Sci Pollut Res 23(5):4742-4752. https://doi.org/10.1007/s11356-015-5695-9

IUNG Environmental Protection Programme for the Province of Silesia to 2019, taking into account prospects for the years 2024 (2015) Katowice (in Polish). Available via DIALOG https:// www.slaskie.pl/zdjecia/2015/08/31/1441024347.pdf

Jankowska J, Sosnowski J, Ciepiela G, Jankowski K (2007) Zawartość ołowiu w wybranych gatunkach roślin dwuliściennych rosnaccych na użytkach zielonych w pobliżu trasy szybkiego ruchu. Ochrona Środowiska i Zasobów Naturalnych 30:99-104. https://doi.org/10.5604/12338273.1058600 (in Polish)

Kabata-Pendias A, Pendias H (2001) Trace elements in soils and plants, 3rd edn. CRC Press, Boca Raton Fla
Kandziora-Ciupa M, Nadgórska-Socha A, Ciepał R, Słomnicki A (2013) Soil contamination with zinc, cadmium and lead in the city of Zabrze. Ecol Chem Eng A 20(1):47-54

Kandziora-Ciupa M, Nadgórska-Socha A, Barczyk G, Ciepał R (2017) Bioaccumulation of heavy metals and ecophysiological responses to heavy metal stress in selected populations of Vaccinium myrtillus L. and Vaccinium vitis-idaea L. Ecotoxicology 26(7):966-980. https://doi.org/10.1007/s10646-017$1825-0$

Keller T, Schwanger H (1977) Air pollution and ascorbic acid. Eur J For Pathol 7:338-350

Kovacs M (1992) Biological indicators in environmental protection. Ellis Horwood, New York

Krishnaveni M (2013) Air pollution tolerance index and antioxidant activity of Parthenium hysterophorus. J Pharm Res 7(2013):296-298. https://doi.org/10.1016/j.jopr.2013.03.025

Kumar M, Nandini N (2013) Identification and evaluation of air pollution tolerance index of selected avenue tree species of urban Bangalore, India. Int $\mathrm{J}$ Emerg Technol Comput Appl Sci 13:388-390

Kurteva M (2009) Comparative study on Plantago major and $P$. lanceolata (Plantaginaceae) as bioindicators of the pollution in the region of the Asarel Copper Dressing Works. Phytologia Balcanica Sofia 15(2):261-271

Kwiatkowska-Malina J, Maciejewska A (2009) Wpływ materii organicznej na pobieranie metali ciężkich przed rzodkiewkę i facelię. Ochrona Środowiska i Zasobów Naturalnych 40:217-223 (in Polish)

Lakshmi P, Sarvant L, Srinivas N (2009) Air pollution tolerance index of various plants species growing in industrial areas, An Int. Biannua. J Environ Sci 2:203-206

Lin A, Zhang X, Zhu Y-G, Zhao F-J (2008) Arsenate induced toxicity: effects on antioxidative enzymes and DNA damage in Vicia faba. Environ Toxicol Chem 27:413-419. https://doi.org/ 10.1897/07-266R.1

Maleci L, Buffa G, Mohammad Wahsha M, Bini C (2014) Morphological changes induced by heavy metals in dandelion (Taraxacum officinale Web.) growing on mine soils. J Soils Sediments 14:731-743. https://doi.org/10.1007/s11368-013-0823-y

Massa N, Andreucci F, Poli M, Aceto M, Barbato M, Berta G (2010) Screening for heavy metal accumulators amongst autochthonous plants in a polluted site in Italy. Ecotoxicol Environ Saf 73:1988-1997. https://doi.org/10.1016/j.ecoenv.2010.08.032

Meerabai G, Venkata-Ramana C, Rasheed M (2012) Effect of industrial pollutants on physiology of Cajanus cajan (L.) Fabaceae. Int J Environ Sci 2(4):1889-1894. https://doi.org/10. 6088/ijes.00202030071

Mincheva T, Barnia E, Varesea G, Brusa G, Cerabolinib B, Siniscalcoa C (2014) Litter quality, decomposition rates and saprotrophic mycoflora in Fallopia japonica (Houtt.) Ronse Decraene and in adjacent native grassland vegetation. Acta Oecologica 54:29-35. https://doi.org/10.1016/j.actao.2013.03. 010

Nadgórska-Socha A, Kandziora-Ciupa M, Ciepał R, Musialik D, Barczyk G (2013a) The activity of selected soil enzymes and soil contamination with zinc, cadmium and lead in the vicinity of zinc smelter "Miasteczko Slaskie". Ecol Chem Eng 20(1):123-131. https://doi.org/10.2428/ecea.2013.20(01)014

Nadgórska-Socha A, Ptasiński B, Kita A (2013b) Heavy metal bioaccumulation and antioxidant responses in Cardaminopsis arenosa and Plantago lanceolata leaves from metalliferous and non-metalliferoussites. Ecotoxicology 22:1422-1434. https://doi. org/10.1007/s10646-013-1129-y

Nadgórska-Socha A, Kandziora-Ciupa M, Ciepal R, Barczyk G (2016) Robinia pseudoacacia and Melandrium album in trace elements biomonitoring and air pollution tolerance index study. 
Int J Environ Sci Technol 13:1741-1752. https://doi.org/10. 1007/s13762-016-1010-7

Ogunkunle C, Suleiman L, Oyedeji S, Awotoye O, Fatoba P (2015) Assessing the air pollution tolerance index and anticipated performance index of some tree species for biomonitoring environmental health. Agroforest Syst 89:447-454. https://doi. org/10.1007/s10457-014-9781-7

Ostrowska A, Gawliński S, Szczubiałka Z (1991) In: Method of analysis and estimate soil and plants property, Catalogue of the Environmental Protection Institute Warsaw, pp 334-336 (in Polish)

Pasieczna A (2003) Atlas zanieczyszczeń gleb miejskich w Polsce. Państwowy Instytut Geologiczny, Warszawa (in Polish)

Pathak V, Tripathi B, Mishra V (2011) Evaluation of anticipated Performance Index of some tree species for green belt development to mitigate traffic generated noise. Urban For Urban Green 10:61-66. https://doi.org/10.1016/j.ufug.2010.06.008

Pilegaard K, Johnsen I (1984) Heavy metal uptake from air and soil by transplanted plants of Achillea millefolium and Hordeum vulgares. In: Ecological Bulletins No. 36 Ecotoxicology: Proceedings of the Third Oikos Conference Held 30 November: 2 December, 1982, in Copenhagen, Denmark (1984), pp 97-102

Polechońska M, Zawadzki K, Aleksandra Samecka-Cymerman A, Klink A, Krawczyk J, Kempers A (2013) Evaluation of the bioindicator suitability of Polygonum aviculare in urban areas. Ecol Ind 24(2013):552-556

Prajapati S, Tripathi B (2008) Seasonal variation of leaf dust accumulation and pigment content in plant species exposed to urban particulates pollution. J Environ Qual 37:865-870. https:// doi.org/10.2134/jeq2006.0511

Przedpełska E, Wierzbicka M (2007) Arabidopsis arenosa (Brassicaceae) from a lead-zinc waste heap in southern Poland-a plant with high tolerance to heavy metals. Plant Soil 299:43-53. https://doi.org/10.1007/s11104-007-9359-5

Radulescu C, Stihi C, Popescu I, Ionita I, Dulama I, Chilian A, Bancuta O, Chelarescu E, Let D (2013) Assesment of heavy metals level in some perennial medical plants by flame atomic absorption spectrometry. Environ Phys 65(1):246-260

Rai P, Panda L (2014) Dust capturing potential and air pollution tolerance index (APTI) of some road side tree vegetation in Aizawl, Mizoram, India: an Indo-Burma hot spot region. Air Qual Atmos Health 7:93-101. https://doi.org/10.1007/s11869013-0217-8
Randhi U, Reddy A (2012) Evaluation of tolerant plant species in urban environment: a case study from $n$ Hyderabad. India Uni J Environ Res Tech 2:300-304

Regulation by the Minister of Environment dated 9 September 2002. Official Gazette No. 165, Pos. 1359th (in Polish). Available via DIALOG. http://prawo.sejm.gov.pl/isap.nsf/download.xsp/ WDU20021651359/O/D20021359.pdf

Romeh A, Metwally S, Khamis M (2016) Potential of Plantago major L. for phytoremediation of lead-contaminated soil and water. Water Air Soil Pollut 227:9. https://doi.org/10.1007/s11270-0152687-9

Singh SK, Rao DN (1983) Proceedings of symposium on air pollution control, vol I. Indian Association for air pollution control, New Delhi, pp 218

Sisodia A, Dutta S (2016) Air pollution tolerance index of certain plant species: a study of national highway no-8, India. J Environ Res Dev 10(04):723

Słomka A, Libik-Konieczny M, Kuta E, Miszalski Z (2008) Metalliferous and non-metalliferous populations of Viola tricolor represent similar mode of antioxidative response. J Plant Physiol 165:1610-1619. https://doi.org/10.1016/j.jplph.2007.11.004

Tinkov A, Nemereshina O, Suliburska J, Gatiatulina E, Regula J, Nikonorov A, Skalny A (2016) Comparative analysis of the trace element content of the leaves and roots of three plantago species. Biol Trace Elem Res 173:225-230

Tripathi A, Gautam M (2007) Biochemical parameters of plants as indicators of air pollution. J Environ Biol 28:127-132

Uka N, Hogarh J, Belford D (2017) Morpho-anatomical and biochemical responses of plants to air pollution. Int J Mod Bot 7(1):1-11. https://doi.org/10.5923/j.ijmb.20170701.01

Update Environment Program for the city of Sosnowiec for 2013-2016 with a perspective for the period 2017-2020. Attachment to the Resolution $\mathrm{Nr} 850 / \mathrm{LI} / 2013$ City Council of Sosnowiec dated 28 November 2013 (in Polish). Available via DIALOG. http://bip.um.sosnowiec.pl/Article/get/id,499582.html

Vanderhoeven S, Dassonville N, Meerts P (2005) Increased topsoil mineral nutrient concentrations under exotic invasive plants in Belgium. Plant Soil 275:169-179

Zhang P, Liu Y, Chen X, Yang Z, Zhu M, Li Y (2016) Pollution resistance assessment of existing landscape plants on Beijing streets based on air pollution tolerance index method. Ecotoxicol Environ Saf 132:212-223. https://doi.org/10.1016/j.ecoenv. 2016.06.003 